\title{
ДИЗЕЛЬНЫЕ ПОДВОДНЫЕ ЛОДКИ РОССИЙСКОЙ ИМПЕРИИ И СССР НА ДАЛЬНЕМ ВОСТОКЕ
}

\section{DIESEL SUBMARINES OF THE RUSSIAN EMPIRE AND THE USSR IN THE FAR EAST \\ V. Semenov}

Summary: The relevance of the article lies in the fact that the author has shown for the first time how the composition, condition of diesel submarines and their tasks changed in the far East since 1904 with the arrival of new submarines to the fleet. The article reveals the role and place of diesel submarines in the submarine forces of the Pacific fleet, and assesses their actions.

Keywords: Pacific fleet, diesel submarines, history, composition, structure, tasks to be solved, combat purpose.
$\mathrm{H}$ а Дальнем Востоке первые подводные лодки появились в Порт-Артуре в 1901-1904 гг., но они не входили в состав флота и не принимали в участие в боевых действиях. Поэтому история подводных сил на Дальнем Востоке начинается с 1904 г., когда Правительство Российской Империи в связи с началом русскояпонской войны приняло решение об усилении морских сил на Дальнем Востоке. С этой целью по железной дороге из г. Санкт-Петербурга и Либавы во Владивосток были отправлены 13 подводных лодок и 2 полуподводные лодки («Чилим» - минный катер, «Кэта» - катер малой видимости). К сожалению, технические качества этих лодок не отвечали условиям Дальневосточного театра военных действий и общим их недостатком была малая дальность плавания.

Первой подводной лодкой во Владивостоке была маленькая экспериментальная подводная лодка «Форель», которая 26 сентября 1904 г. прибыла в собранном виде на 4-осной железнодорожной платформе. Следом за «Форелью» последовала на 2-осной железнодорожной платформе крохотная подводная (точнее, полуподводная) лодка конструкции лейтенанта Боткина. В декабре 1904 г. в составе Отдельного отряда миноносцев Владивостокского отряда крейсеров было уже 6 подводных лодок и 1 полуподводная лодка, одна из которых (подводная лодка «Сом») впервые в истории флота России 29 апреля 1905 г. атаковала японские миноносцы в районе острова Русский, тем самым подтвердив, что подводные лодки стали реальной силой на море, способной самостоятельно решать боевые задачи. В июне-июле 1905 г. 8 подводных лодок закончили практическую подготовку личного состава и начали нести дозорную службу у Русского острова и острова Аскольд, оставаясь там целыми

\author{
Семёнов Виктор Николаевич \\ К.т.н., Дальневосточный федеральный университет \\ (Владивосток). \\ viktor_55@mail.ru
}

Аннотация: Актуальность статьи заключается в том, что автор впервые показал, как с 1904 г. на Дальнем Востоке менялись состав, состояние дизельных подводных лодок, решаемые ими задачи с поступлением на флот новых подводных лодок. В статье раскрыты роль и место дизельных подводных лодок в составе подводных сил Тихоокеанского флота, и дана оценка их действиям.

Ключевые слова: Тихоокеанский флот, дизельные подводные лодки, история, состав, структура, решаемые задачи, боевое назначение.

сутками. По мере накопления опыта и тренировки личного состава лодки выходили и в отдалённые районы. Наличие отряда подводных лодок сыграло определенную роль при отказе японского командования от тесной блокады крепости. Оно ограничило свою деятельность в этом районе периодическими посылками одного-двух миноносцев для ведения разведки. Не исключено, что страх перед подводными «адскими машинами», способными торпедировать любой броненосец, оставаясь незамеченными, оказался сильнее огня крепостных орудий.

11 марта 1906 г. по Морскому ведомству морским Министром вице-адмиралом А.А. Бирилёвым был подписан приказ № 52, которым в классификацию судов военного флота внесены подводные лодки. Подводные лодки стали самостоятельным классом кораблей Российского флота - классом кораблей, которым страна может гордиться вот уже более ста лет.

В 1915-1916 гг. для усиления боевого состава морских сил на Балтике и на Чёрном море из Владивостока по железной дороге были отправлены подводные лодки «Щука», «Сом», «Налим», «Скат» (в Севастополь), «Фельдмаршал граф Шереметев», «Касатка» (на Балтику). Последняя подводная лодка дивизиона подводных лодок Сибирской флотилии «Дельфин» 23 мая 1916 г. по железной дороге покинула Владивосток. С её отправкой 16 с половиной лет на Дальнем Востоке не было подводных лодок.

В 1932 г. в ответ на агрессивную позицию милитаристской Японии правительство СССР приняло решение о создании Морских сил Дальнего Востока (МС ДВ) 
СССР - ТОФ СССР и его подводных сил. 25 февраля 1932 г. Народный комиссар Обороны и председатель Революционного Военного Совета (РВС) СССР К.Е. Ворошилов утвердил «План мероприятий по сформированию Морских Сил Дальнего Востока». По плану к концу 1933 г. должно быть закончено формирование флота в состав, которого должны были войти бригады средних подводных лодок типа «Щ» (12 ед.) и малых подводных лодок типа «М» (30 ед.) [1, с. 585]. В составе МС ДВ приступили к формированию соединений подводных сил, способных решать задачи по обеспечению безопасности СССР в водах омывающих дальневосточное побережье морях.

К середине 1932 г. на Дальзавод во Владивостоке и Судомеханический в Хабаровске для достройки и проведения испытаний начали поступать по железной дороге в разобранном состоянии корпуса и механизмы первых подводных лодок типа «Щ» $\mathrm{V}$ серии и на следующий год - целиком лодки типа «М», построенные на судостроительных заводах Ленинграда и Николаева. Первая советская подводная лодка под тактическим номером Щ-11 была спущена на воду в бух. Золотой Рог 12 декабря 1932 г., с неё и началось создание подводных сил.

В соответствии с решением ВКП 6 и Правительства СССР в 1932 г. началась постройка 12 подводных лодок типа «Щ» для Тихого океана. Их секциями доставляли по железной дороге с последующей сборкой на Дальзаводе № 202 (г. Владивосток) и Судомеханическом заводе № 368 (Осиповский затон, г. Хабаровск). До конца 1933 г. МС ДВ СССР получили 8 подводных лодок типа «Щ» серии V. Всего за 1933-1936 гг. в состав флота поступили подводные лодки типа «Щ» разных серий: серии V - 12 ед., серии V-бис (7) - 4 ед., серии X (V-бис2) - 5 ед., серии X (V-бис3) - 10 ед., серии X-бис - 4 ед.

Вслед за подводными лодками типа «Щ» в состав флота стали поступать подводные лодки типа «M» VI ceрии , первая из которых прибыла во Владивосток 6 января 1934 г. Через два года в составе МС ДВ их было 28 единиц. Это была цельносварная подводная лодка малого водоизмещения. По надводному водоизмещению подводная лодка типа «М» занимала промежуточное положение между торпедными катерами и охотниками за подводными лодками. Главной головной болью командиров лодок было отсутствие на них цистерн быстрого погружения. По этой причине «малютки», во-первых, медленно погружались, а во-вторых, при стрельбе торпедами с перископной глубины обычно всплывали на поверхность почти до уровня палубы. Основной задачей «малюток» VI серии было несение дозора на подходах к базам.

Во второй половине 30-х гг. в состав ТОФ вошли 13 подводных минных заградителей типа «Ленинец» (серии XI- 6 ед., XIII- 7 ед.). Минные заградители прибыли по железной дороге и были собраны на заводе №199, г.
Комсомольск-на-Амуре - 6, на заводе № 202 «Дальзаводе», г. Владивосток - 7. В 1939 г. на флот продолжили поступать подводные лодки типа «М»: серии VI-бис - 6 ед., серии XII - 3 ед.

В 40-е годы подводные силы ТОФ продолжали расти, в их состав поступили новые подводные лодки (13 ед.) типа «С» серии IX-бис и серии IX-бис 2.

Сразу после приёма подводной лодки в состав флота подводники приступали к активной боевой подготовке, которая не прекращалась ни зимой, ни летом. В начале 1934 г. подводная лодка «Лещ», выходя из бухты на боевую подготовку, первой совершила плавание подо льдом, пройдя около 5 миль. В том же году «Карп» и «Налим» первыми совершили дальний учебный поход вдоль берегов Приморья. Во второй половине 1935 г. подводная лодка Щ-103 («Карп») совершила непрерывное 58-часовое подводное плавание, пройдя под электродвигателями экономичного хода более 150 миль, что значительно превысило проектную норму. Практика показала, что подводные лодки типа «Щ» располагали большими скрытыми резервами. Подводникам - тихоокеанцам, например, удалось увеличить автономность по сравнению с нормой в 2 - 3,5 раза. Подводная лодка Щ-117 находилась в море 40 суток (при норме 20 суток), установив также рекорд пребывания под водой на ходу - 340 часов 35 минут. За это время Щ-117 прошла 3022, 3 мили, из них под водой 315,6 миль. Весь личный состав этой подводной лодки был награждён орденами. Эта подводная лодка стала первым в истории ВМФ СССР кораблём с полностью орденоносным экипажем. В августе-сентябре 1935 г. 5 подводных лодок типа «Щ» в сопровождении плавбазы «Саратов» осуществили продолжительное совместное плавание. В период с 14 сентября по 25 декабря 1936 г. подводная лодка Щ-113 («Стерлядь») серии V - бис выполнила 103-суточный поход. Щ-113 первой в течение часа ходила под дизелями на перископной глубине. В 1936 г. дивизион подводных лодок типа «Щ» пробыл в походе 46 суток. Новые сроки автономности самых многочисленных по численности в советском ВМФ подводных лодок типа «Щ», вдвое увеличенные по сравнению с прежними, были официально утверждены наркомом обороны. В 1937 г. подводная лодка Щ-105 впервые была использована в условиях Дальнего Востока для научных плаваний. Во время плавания в Японском и Охотском морях она выполняла под руководством профессора Л.А. Сорокина гравиметрические съёмки - определение ускорения тяжести на земной поверхности.

На начальном этапе строительства подводных сил в составе флота подводные лодки были сведены в 2 бригады подводных лодок: 1-я (бух. Золотой Рог, 22.09.1933 г.), 2-я (бух. Малый Улисс, 15.04.1934 г.) и Сводный отряд подводных лодок (бух. Находка, 14.11.1934 г.). К январю 
1935 г. в составе МС ДВ было 42 подводные лодки (26 малые, 16 - средние).

11 января 1935 г. Народный комиссар обороны СССР приказом № 9 потребовал изменить наименование Морских сил и впредь именовать: Морские силы Дальнего Востока - Тихоокеанский флот (ТОФ), о чём было объявлено приказом командующего ТОФ от 14 января 1935 г. № 016.

Количество подводных лодок в составе ТОФ продолжало расти, и они были сведены в 5 бригад подводных лодок( 1-я - в б. Золотой Рог, 2-я - в б. Малый Улисс, 3-я - в б. Находка, 4-я - в б. Золотой Рог, 5-я - в б. Постовая) и 3 отдельных дивизиона подводных лодок (41-й - на Камчатке, учебный - в б. Золотой Рог, при учебном отряде подводных лодок в б. Малый Улисс). Но апреле-мае 1941 г. соединения подводных лодок подверглись реорганизации:

- количество бригад уменьшилось до 3 (1-я в бух. Золотой Рог, 2-я в бух. Улисс, 3-я в бух. Постовая), при этом каждая бригада состояла из 3 дивизионов, а количество подводных лодок в каждой бригаде увеличилось;

- стало 3 отдельных дивизиона (1-й - в б. Находка, 2-й - в з. Владимира, 3-й - на Камчатке) и 2 отдельных учебных дивизиона (в бух. Золотой Рог все достраивающиеся и капитально ремонтирующиеся подводные лодки, в бух. Малый Улисс 4 подводные лодки при учебном отряде подводного плавания).

В составе подводных сил ТОФ было 85 подводных лодок.

Во время Великой Отечественной войны подводные лодки ТОФ активных боевых действий не вели, а участие подводных сил ТОФ в советско-японской войне были сведены к ведению разведывательных действий, дежурству на позициях, поддержке десанта. Боевые успехи (потопление судов) были незначительные.

В январе 1947 г. решением правительства СССР ТОФ СССР был разделен на два флота: 5-й ВМФ СССР и 7-й ВМФ СССР. Главная база 5-го ВМФ СССР находилась в г. Владивостоке, а главная база 7-го ВМФ СССР находилась в Советской Гавани. Подводные силы ТОФ были разделены на две части по территориальному принципу. К 5-му ВМФ СССР были приписаны соединения подводных лодок, базирующиеся во Владивостоке, в з. Владимира, в Порт-Артуре. В состав 7-го ВМФ СССР вошли соединения подводных лодок, базирующиеся в зал. Советская гавань и в бух. Тарья на Камчатке. За время раздельного существования 5-го и 7-го ВМФ, для их укрепления в19511953 гг. поступили 26 новые подводные лодки типа «М» серии XV (проект 96) - двухвальные подводные лодки малого водоизмещения с увеличенным торпедным бо- езапасом (4 торпеды), которые прослужили в составе флота до конца 60-х и были выведены из боевого состава флота, как устаревшие и несоответствующие требованиям времени.

В связи с количественным ростом подводных сил в 5-м ВМФ вместо 3 бригад стало 4 бригады подводных лодок (также был сформирован 52-й дивизион строящихся и ремонтирующихся подводных лодок), а в 7-м ВМФ количество бригад выросло до 3. В апреле 1951 г. в составе флотов были сформированы первые 2 дивизии дизельных подводных лодок: в Приморье - 40-я дивизия и 16-я дивизия на Камчатке.

23 апреля 1953 г. решением правительства СССР 5-й и 7-й ВМФ СССР были объединены в ТОФ СССР [10]. Основные подводные силы были сконцентрированы в районе Приморья - 40-я дивизия (123-я бригада - бух. Малый Улисс, 124-я бригада - бух. Большой Улисс, 171-я бригада - бух. Находка, 126-я отдельная бригада - зал. Владимира) и по одной бригаде подводных лодок на Камчатке - 182-я, в зал. Советская Гавань - 90-я, в ПортАртуре - 125-я.

В составе подводных сил были подводные лодки морально и технически устаревших проектов, которые уже не позволяли решать в полном объёме стоящие перед ТОФ задачи. Поэтому в середине 50-х гг. началось перевооружение подводных сил ТОФ:

- в 1954 г. начали поступать средние торпедные дизель-электрические подводные лодки проекта 613. Всего за десть лет в состав ТОФ вошли 60 подводных лодок. Эти подводные лодки обладали большими боевыми возможностями, чем имеющиеся в это время на флоте подводные лодки (типа «Л», «М» и «С»);

- с 1955 г. по 1960 г. прибыли 8 больших (океанских) торпедных подводных лодок проекта 611, которые должны были вести боевые действия на океанских коммуникациях и у пунктов базирования противника.

Подводные лодки проектов 613 и 611 стали решать задачи автономных походов:

- подводные лодки проекта 613 с автономностью плавания 50 суток были способны выполнять боевую задачу на морском театре войны;

- подводные лодки проекта 611 с автономностью плавания 75 суток были способны успешно действовать на океанских путях и у отдалённых баз против военных кораблей, конвоев и одиночных транспортов противника, решать задачи разведки в дальних районах, прикрывать свои конвои на океанских путях, а также ставить минные банки на путях следования кораблей противника.

Впервые подводные лодки флота с боевыми задача- 
ми ведения разведки вышли в автономные походы: 16 июля 1956 г. первой в такой поход была направлена подводная лодка С-87 (командир - капитан 3 ранга В.Н. Поникаровский), которая прошла до $175^{\circ}$ западной долготы, обогнув почти всю северную часть Тихого океана. Вслед за ней выполнили дальние походы с теми же задачами подводная лодка С-173 (командир - капитан 2 ранга В.М. Смертин) в Чукотское море и С-91 (командир - капитан 3 ранга В.П. Милованов) в район атолла Мидуэй.

В 1958 г. в истории подводных сил ТОФ началась эпоха ракетного подводного флота: поступили совершенно новые по своим боевым возможностям и боевому предназначению подводные лодки, вооружённые ракетным оружием. Ими стали 2 большие ракетные дизель-электрические подводные лодки проекта AB611 (каждая несла на борту 2 баллистические ракеты Р-11ФМ надводного старта). Наличие на флоте двух дизельных подводных лодок с баллистическими ракетами (2 подводные лодки имели по 2 ракеты) не могло повлиять на боевые возможности флота, но с них началось освоение нового оружия. Первыми командирами ракетоносцев были капитан 3 ранга В.А. Дыгало и капитан 2 ранга Н.Ф. Ханин

Значительной вехой в истории подводных сил ТОФ стал 1960 г., когда произошли три очень значимых события:

- продолжили поступать ракетные подводные лодки, но это были уже серийные подводные лодки с баллистическими ракетами проекта 629;

- прибыли большие (океанские) дизельные подводные лодки проекта 641;

- поступила новая по своему боевому предназначению дизельная подводная лодка с крылатыми ракетами проекта 644.

Подводные лодки проекта 629 - специальный проект подводной лодки с баллистическими ракетами Р-13, с 3 ракетными шахтами. Ракетный комплекс Д-2 с ракетами P-13 имел существенно повышенную ударную мощь (3 ракеты вместо 2), и главное, почти в 4 раза была увеличена дальность стрельбы (600 км против 160 у Р-11ФМ с ядерной боеголовкой мощностью 1 Мт) [1]. По сравнению с ракетными лодками AB-611 подводная лодка проекта 629 обладала рядом преимуществ: были увеличены предельная глубина погружения и дальность плавания в надводном положении и в режиме «работа дизеля под водой». Всего на ТОФ поступило 11 ед. Строительство подводных лодок проекта 629 велось на заводе № 402 на Севере и заводе № 202 им. Ленинского комсомола на Дальнем Востоке [4, с. 42]. Появление в составе флота подводных лодок с баллистическими ракетами потребовало изменения в боевой подготовке подводных лодок, соединений подводных лодок, отработки взаимодействия с другими силами. Начиная с 1963 г. подводные лодки проекта 629 прошли модернизацию по проекту
629A, в результате которой они получили на вооружение ракеты Р-21 (комплекс Д-4) с подводным стартом и дальностью стрельбы до 1400 км [6, с. 89, 92]. Стрельба производилась с глубины до 50 м, при волнении моря до 5 баллов и скорости подводной лодки до 4 узлов. Время между стартами первых 2 ракет составляло около 5 мин [9, с. 276]. Это были первые серийные корабли ВМФ СССР, имевшие на борту баллистические ракеты с подводным стартом. Они долго оставались в строю, и только к началу 1990-х гг. ввиду морального и технического устаревания были выведены из состава флота [7, с. 28]. Первыми командирами этих подводных лодок были капитаны 2 ранга К.Д. Подольский, Н.И. Суздалев, В.И. Кобзарь, А.П. Симоненко, В.С. Сысуев, Ю.Н. Калашников, В.К. Пятов, И.И. Людмирский, Э.А. Абраменко, Л.А. Шабалин, Г.А. Малышевский, Ф.М. Луговской, капитаны 1 ранга Я.М. Ушаков, Э.Д. Логинович. В составе ТОФ (1958-1991 гг.) было 15 дизельных подводных лодок с баллистическими ракетами: 2 - проекта АВ611 (прибыли в1958 г.), 13 - проекта 629, 629A (6 ед. прибыли 1968-1964 гг. с СФ, 7 ед. построены на ССЗ № 199 в г. Комсомольск - на - Амуре 1960-1962 гг.). К 1970 г. в составе ТОФ 8 подводных лодок с баллистическими ракетами были в боевом составе проекта 629. Общее количество подводных лодок с баллистическими ракетами, несмотря на поступление новых - снизилось, так как подводные лодки проекта AB611 (-2) были выведены из состава флот (1967 г.), а подводная лодка проекта 629 (К-129, командир - капитан 1 ранга В.И. Кобзарь) погибла в 1968 г. находясь на боевой службе. Эти подводные лодки, не смотря на технические недостатки и не большие боевые возможности, благодаря мастерству командиров, самоотверженности экипажей, ходили на боевую службу и несли боевое дежурство, представляли реальную угрозу для вероятного противника и обеспечивали военную безопасность СССР в Азиатско - Тихоокеанском регионе.

Большие дизель-электрические подводные лодки проекта 641 были океанскими, т.е. могли вести боевые действия на дальних коммуникациях, осуществлять минные постановки, вести разведку и противолодочные действия. До 1973 г. в состав ТОФ вошли 17 подводных лодок проекта 641: осуществили межфлотские переходы по Северному морскому пути - 15 ед., южным маршрутом - 2 ед. Торпедные подводные лодки проекта 641 были основными в своём классе и только в 1981 г. им на смену стали поступать торпедные дизель-электрические подводные лодки проекта 877.

С прибытием на ТОФ подводных лодок проектов 641 и 629 было обеспечено постоянное присутствие наших сил в ближней зоне ТОФ, в удалённых районах Тихого океана, вплоть до западного побережья США. Подводные лодки проекта 629 способны были наносить ракетно-ядерные удары по стратегическим объектам, расположенным на западном побережье США. Автономные 
походы на начальном этапе носили эпизодический характер.

Дизельная подводная лодка с крылатыми ракетами проекта 644 C-44 (на вооружении 2 крылатые ракеты П-5 надводного старта) стала родоначальником важного элемента подводных сил ТОФ - подводных лодок с крылатыми ракетами, главная задача которых стала борьба с надводными кораблями противника. Подводная лодка C-44 (командир - капитан 2 ранга П.И. Бочаров) прибыла на ТОФ с СФ Северным морским путём в состав 124-й бригады подводных лодок 40-й дивизии подводных лодок и прослужила до 1968 г.

До середины 60-х гг. в состав ТОФ продолжали прибывать подводные лодки новых проектов:

- в 1961 г. - дизельная подводная лодка радиолокационного дозора проекта 640, которая вошла в 19-ю бригаду подводных лодок;

- в 1962 г., совершив межфлотский переход по трассе Северного морского пути в надводном положении, прибыли 2 дизельные подводные лодки с крылатыми ракетами проекта 665 C-61 (командир - капитан 3 ранга А.Г. Болтнев) и С-64 (командир капитан 2 ранга В.В. Яскевич), они имели на вооружении 4 крылатых ракеты П-5 надводного старта. Подводные лодки вошли в состав 124-й бригады подводных лодок 6-й эскадры подводных лодок.

В мае 1962 г. для участия в боевых действиях в Индонезии в 6-й эскадре подводных лодок была сформирована 54-я отдельная бригада подводных лодок (командир бригады - контр-адмирал Рулюк А.А.). В состав бригады вошли 6 подводных лодок проекта 613: С-292 (капитан 2 ранга Таргонин Г.В.), С-236 (капитан 2 ранга Дворников Ю.В.), С-235 (капитан 2 ранга Швандеров Ю.Г.), С-239 (капитан 2 ранга Протасов П.А.), С-290 (капитан 2 ранга Кодес А.А.), С-391 (капитан 2 ранга Антипов А.Н.). С приходом в порт Сурабая лодки с советскими экипажами были сведены на время операции «Алюгоро» (так условно в индонезийском штабе ВМС обозначалась операция по освобождению Ириан Джая) в 50-ю оперативную бригаду подводных лодок ВМФ, куда вошли ещё 6 подводных лодок проекта 613 с индонезийскими экипажами (лодки были переданы в 1959 и 1962 гг.). Участие подводных лодок ТОФ в операции «Алюгоро» внесло вклад в успех мирного решения индонезийско - голландского территориального конфликта.

С ростом подводных сил росло и число походов в удалённые районы океана. В середине 60-х гг. эпизодические автономные походы стали превращаться в регулярную боевую службу. Боевая служба - высшая форма поддержания боеготовности сил флота и применения сил ВМФ в мирное время. Цели боевой службы были определены как: «поддержание боевой готовности сил к решению поставленных им задач с началом военных действий и обеспечение интересов страны в оперативно важных районах Мирового океана» [2, с. 131].

Дизельные подводные лодки стали первопроходцами в освоении глубин на океанских просторах со всеми сложностями, трудностями и бедами, присущими первопроходцам. В 1964 г. в удалённые районы Тихого океана дизельные подводные лодки совершили 5 походов. По освоенным ими маршрутам продолжили освоение океанов атомные подводные лодки ТОФ.

В течение 1965-1966 гг. увеличилась интенсивность выхода на боевую службу подводных лодок: 4 дизельные подводные лодки с баллистическими ракетами проекта 629A решали задачи по нанесению ракетно-ядерных ударов по береговым объектам на западном побережье США; задачи поиска, слежения за авианосно-ударными группами США решала1 дизельная подводная лодка с крылатыми ракетами проекта 665; задачи разведки, противолодочной борьбы решали дизельные торпедные подводные лодки (10 средние - проекта 613, 1 большая океанская - проекта 611, 1 большая - проекта 641). Районами несения боевой службы были Филиппинское и Японское моря и Тихий океан, а средняя продолжительность несения боевой службы составляла 30-60 суток.

В 1965-1969 гг. в состав ТОФ вошли 4 дизельные подводные лодки с крылатыми ракетами проекта 651 (командиры - капитаны 2 ранга В.И. Бец, Д.В. Никитин, Ю.В. Дворников, В.С. Любимов). На этом закончилась серия из 7 ед. дизельных подводных лодок с крылатыми ракетами.

Кроме подводных лодок с баллистическими ракетами, с крылатыми ракетами и многоцелевых лодок, которые определяли боевые возможности флота, на ТОФ были подводные лодки специального назначения, построенные на СС3 им. Ленинского комсомола, г. Комсомольск-на-Амуре:

- в 1967-1970 гг. были приняты в состав флота 4 средних подводных лодки - мишени проекта 690, шифр «Кефаль» (3 - были переданы на ЧФ и СФ) для обеспечения испытаний новых систем противолодочного оружия и для участия в противолодочных учениях в качестве подводной лодки мишени (могла также использоваться в качестве боевой подводной лодки);

- 1976-1979 гг. в состав ТОФ вошли 2 большие спасательные подводные лодки проекта 940 шифр «Ленок», предназначенные для аварийно - спасательных работ и спасения экипажей с затонувших подводных лодок.

В 1970 г. дизельные подводные лодки ещё были основным подклассом в составе подводных сил ТОФ из 131 подводной лодки было 103 дизельных подводных лодки: с баллистическими ракетами (проекта 629, 629A) - 8 ед., 
с крылатыми ракетами (проектов 644, 665, 651) - 7 ед., многоцелевые или торпедные (проектов 611, 641, 613) 85 ед., а также подводные лодки специального назначения (проектов 640, 690) - 3 ед.

В 1978 г. в бух. Конюшкова зал. Стрелок на базе 124-й бригады подводных лодок была сформирована 9-я дивизия подводных лодок 6-й эскадры. В состав дивизии вошли 7 дизельных подводных лодок с баллистическими ракетами: 5 - проекта 629, 2 - проекта 629A, 1 - проекта 629Р [ЦАМО АО ТОФ. Д. ф. 1675, л. 111].

В 1981 г. в состав ТОФ начали поступать большие торпедные дизель-электрические подводные лодки проекта 877 (до 1990 г. 10 ед.), которые были предназначены для борьбы с надводными кораблями и подводными лодками, постановки минных заграждений, ведения разведки. Одно из главных достоинств этих подводных лодок - низкий уровень шумности. Все подводные лодки проекта 877были построены на СС3 им. Ленинского комсомола (г. Комсомольск-на-Амуре).

В 1983 г. подводные силы ТОФ достигли своего могущества: в составе флота было133 подводные лодки, из них - 71 атомная и 63 - дизельные.

В этот период появилась тенденция сокращения в составе флота количества дизельных подводных лодок и рост количества атомных подводных лодок. Количество дизельных подводных лодок уменьшилось почти в 2 раза (на 49 \%): в 1970 г. - 103 ед., в 1984 г. - 62 ед., в 1986 г. - 53 ед. И напротив, количество атомных подводных лодок за этот же период возросло почти в 3 раза: в 1970 г. - 28 ед., в 1984 г . - 71 ед., в 1986 г. - 74 ед. В 1984 г. количество атомных и дизельных подводных лодок практически сравнялось (71 и 62), но в 1986 г. это соотношение стало уже 74 к 53 (всего - 127). Это объясняется рядом преимуществ атомных подводных лодок. Основной ударной силой стали атомные подводные лодки. Как следствие: в составе ТОФ сокращалось количество бригад дизельных подводных лодок, но формировались новые дивизии атомных подводных лодок.

Общее количество подводных лодок на ТОФ к 1989 г. уменьшилось до 117: доля атомных выросла до 76 ед., дизельные были представлены 41 ед.

В 1989-1990 гг. продолжается выполнение подводными лодками традиционных для флота задач - несение боевой службы в морях, прилегающих к нашему побережью, для обеспечения боевой устойчивости ракетных подводных лодок стратегического назначения и с целью вскрытия и затруднения разведывательной деятельности Военно-морских сил вероятного противника; несение боевой службы в Индийском океане и ЮжноКитайском море; выявление районов патрулирования атомных подводных лодок с баллистическими ракетами и слежение за авиационно-ударными группировками разнородно-ударными группировками. С 1986 г. по 1991 г. наблюдается сокращение количества несения боевых служб подводными лодками ВМФ СССР: ракетными подводными лодками стратегического назначения с 76 до 38 (на 50 \%), атомными подводными лодками с крылатыми ракетами с 54 до 19 (на 70 \%), дизельными подводными лодками с 33 до 16 (на 50 \%) [3]. На ТОФ подводными лодками было совершено походов в 1989 г. 11 (из них 4 - атомных), а в 1990 г. - 10 (из них 3 - атомных).

В разные годы в состав ТОФ входили 18 бригад дизельных подводных лодок, эти бригады существовали в составе флота от 2 до 30 лет, но все эти годы они обеспечивали военную безопасность нашей страны в Азиатско - Тихоокеанском регионе.

Дизельные подводные лодки Морских сил Дальнего Востока СССР - Тихоокеанского флота СССР прошли путь от малых подводных лодок типа «Малютка» до крейсерских подводных лодок с баллистическими ракетами проекта 629A, крейсерских подводных лодок с крылатыми ракетами проекта 651, больших подводных лодок проекта 877. Дизельные подводные лодки ТОФ от действий по боевому предназначению в прибрежной зоне, затем в прибрежных морях, с начала 60-х гг. вышли в открытый океан и были способны эффективно вести боевые действия против боевых надводных кораблей, подводных лодок, транспортов и судов противника в любых районах Мирового океана. Особую дань уважения и признательности нужно отдать подводникам-тихоокеанцам, чья служба на дизельных подводных лодках (боевые службы по несколько месяцев) проходила на грани человеческих возможностей (особенно в южных широтах). Не менее тяжёлой была служба в суровых условиях Камчатки: жестокие морозы, льды, ледяные и снежные ураганы, беспросветные туманы и тяжёлые условия жизни в гарнизонных городках (бух. Нагаева, бух. Бечевинская).

К 1991 г. в составе ТОФ от былой армады дизельных подводных лодок осталось только 2 бригады подводных лодок (19-я в бух. Улисс и 182-я в бух. Бечевинская).

Дизельные подводные лодки (РИФ и ВМФ СССР) на Дальнем Востоке в XX-м веке представляли серьёзную силу и были способны решать задачи, стоящие перед подводными силами по защите интересов страны, и влиять на геополитику в Азиатско-Тихоокеанском регионе. С середины 70-х гг., когда в составе подводных сил появились атомные подводные лодки и стали основным подклассом подводных лодок, дизельные подводные лодки продолжали решать в составе флота, свойственные им задачи. 


\section{ЛИТЕРАТУРА}

1. Березовский, Н.Ю. Боевая летопись Военно-Морского Флота, 1917-1941. /Н.Ю. Березовский, С.С. Бережной, З.В. Николаева. - М.: Воениздат, 1992. - 838 с.

2. Главный штаб ВМФ: история и современность. 1967-1997. М.: Научная книга, 1998. - 186 с.

3. Золотов А.Н., С.К. Свирин, П.П. Шамаев, С.В. Кочергин. Основные военные проблемы создания современного флота. Проблемы, вставшие перед ВМФ и военной наукой (1986-1996 гг.). [Электронный ресурc]. / URL. https://flot.com/science/sf1.htm?print=Y (дата обращения 24.02.2019).

4. Карпенко А.В., Н.И. Шумков «Морские комплексы с баллистическими ракетами», СПб. - Москва, 2009 г. - 144 с.

5. Крамаренко В.Г. Подводные силы ВМФ СССР в период решения задач стратегического сдерживания в Мировом океане в 1960-1980 годы. Труды научноисторической военно-морской конференции «Подводные силы России на службе Отечеству. История и современность». Санкт-Петербург, 2006. - 26-40 c.

6. Надводные корабли, суда и подводные лодки постройки завода № 402 - ФГУП «ПО «Севмаш» (1942-2001): Справочник/ Авт.-сост. Спирихин С.А. - Изд. 2-е, исп. и доп. - Архангельск: ОАО «ИПП «Правда Севера», 2006. - 242 с.

7. Павлов А.С. Военные корабли СССР и России 1945-1995 г. Справочник. Вып. З. Якутск: «Сахаполиграфиздат», 1995. - 208 с.

8. Стратегический подводный флот СССР и России. А.Б. Колдобский, МИФИ, г. Москва. [Электронный ресурc] / URL. // https://fiz.1sept.ru/2001/05/no05_1.htm (дата обращения 10.12.2019).

9. Стратегическое ядерное оружие России. Кол. авторов под ред. Подвига П.Л. - М.: ИздАТ. 1998. - 492 с.

10. 288 лет Тихоокеанскому флоту: от ладей Охотской флотилии до ракетных крейсеров. [Электронный ресурc] / URL. Prima Media https://primamedia. ru/ news/ 507342/ (дата обращения 18.12.2019).

11. ЦАМО АО ТОФ (Центральный архив МО арх. отд. ТОФ).

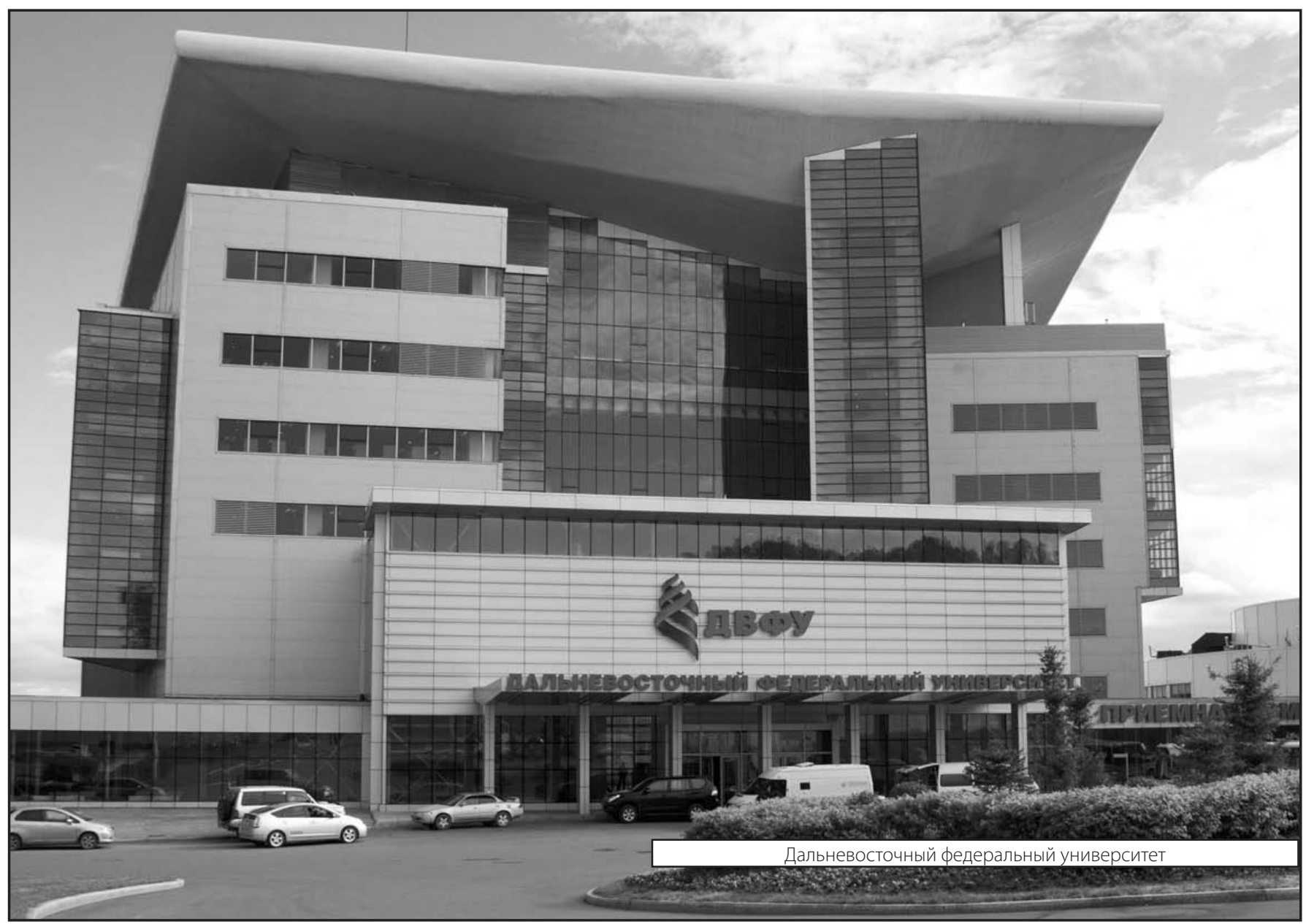

